\title{
PReS-FINAL-2356: A comparison of the American college of rheumatology and the systemic lupus international collaborating clinics classification criteria for systemic lupus erythematosus using data from the uk juvenile systemic lupus erythematosus cohort study
}

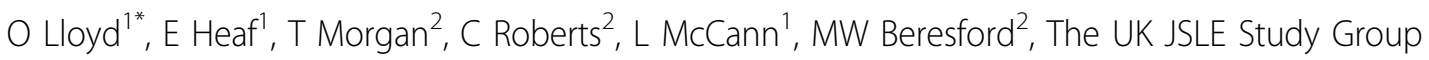 \\ From 20th Pediatric Rheumatology European Society (PReS) Congress \\ Ljubljana, Slovenia. 25-29 September 2013
}

\section{Introduction}

Significant differences in disease onset and course have been described in adults and children with SLE. Making a diagnosis of JSLE is complex. The United Kingdom JSLE Cohort Study[1] collects demographic and prospective clinical data on patients fulfilling the ACR classification criteria for SLE $\leq 18$ years of age and those with probable evolving disease from time of diagnosis onwards. In 2012 the SLICC group proposed a new classification designed to enhance and improve the diagnosis of SLE. The aim of our study is to determine if the SLICC classification facilitates earlier diagnosis of SLE in a large juvenile cohort.

\section{Objectives}

- To define the number of patients in the UK JSLE Cohort Study not meeting the ACR criteria but identified as having lupus at diagnosis by SLICC classification criteria using data collected at baseline.

- To identify the number of patients who met the ACR criteria at diagnosis but do not meet the SLICC criteria.

\section{Methods}

We compared data collected at diagnosis in two groups of patients, those with $\geq 4$ ACR criteria and those with

'Department of Paediatric Rheumatology, NHS, University of Liverpool, Liverpool, UK

Full list of author information is available at the end of the article $\leq 3$ ACR criteria (probable evolving disease, as defined by consultant paediatric rheumatologist). Some SLICC criteria variables could not be applied (eg. toxic epidermal necrolysis, some forms of chronic cutaneous lupus and $\mathrm{CH} 50$ ) because they are not collected in the UK JSLE Cohort dataset. Data were available for 245 patients.

\section{Results}

In our cohort $192(78.4 \%)$ patients met $\geq 4$ ACR criteria and $53(21.6 \%)$ had $\leq 3$ ACR criteria at diagnosis. Of those with $\leq 3$ ACR criteria, 31(58.5\%) were identified as having lupus by application of the new SLICC criteria. In patients identified at diagnosis by SLICC, one patient met the criteria due to biopsy confirmed lupus nephritis and positive ANA. Of the 192 patients with $\geq 4$ ACR, only three $(1.6 \%)$ failed to meet the SLICC criteria at diagnosis.

\section{Conclusion}

In our cohort of JSLE patients, application of the SLICC classification criteria increased the chance of a definite diagnosis of JSLE compared to use of ACR criteria. This suggests that use of SLICC criteria, which includes greater weighting of immunological criteria, may improve sensitivity for diagnosis of SLE in children and young people. This is of particular relevance for a paediatric population susceptible to a more aggressive disease process, where 
an earlier diagnosis could ultimately improve disease outcome. Further studies are needed to assess sensitivity and specificity of SLICC criteria in paediatric lupus.

\section{Disclosure of interest}

None declared.

\section{Authors' details}

'Department of Paediatric Rheumatology, NHS, University of Liverpool, Liverpool, UK. ${ }^{2}$ Institute of Translational Medicine (Child Health), University of Liverpool, Liverpool, UK.

Published: 5 December 2013

\section{Reference}

1. Watson L, et al: Arthritis Rheum 2012, 64(7):2356-6, Jul.

doi:10.1186/1546-0096-11-S2-P346

Cite this article as: Lloyd et al:: PReS-FINAL-2356: A comparison of the

American college of rheumatology and the systemic lupus international

collaborating clinics classification criteria for systemic lupus

erythematosus using data from the uk juvenile systemic lupus

erythematosus cohort study. Pediatric Rheumatology 2013

11(Suppl 2):P346.

Submit your next manuscript to BioMed Central and take full advantage of:

- Convenient online submission

- Thorough peer review

- No space constraints or color figure charges

- Immediate publication on acceptance

- Inclusion in PubMed, CAS, Scopus and Google Scholar

- Research which is freely available for redistribution

Submit your manuscript at www.biomedcentral.com/submit
Ciomed Central 